Industrial Health, 1980, 18, 129.

\title{
ANION EXCHANGE CHROMATOGRAPHIC PROPERTIES OF URINARY METALLOTHIONEIN AND ITS ROLE IN CADMIUM, COPPER AND ZINC EXCRETION IN CADMIUM-POISONED RATS
}

\author{
Yasutomo SUZUKI \\ National Institute of Industrial Health, 21-1, Nagao 6 chome, \\ Tama-ku, Kawasaki 213 Japan
}

(Received March 5, 1980)

\begin{abstract}
Urine of rats given daily subcutaneous injection of $0.5 \mathrm{mg} \mathrm{Cd} / \mathrm{kg}$ for 14 weeks was chromatographed on a Sephadex G-75 column. The eluted fractions were analyzed for cadmium, copper and zinc. A cadmium- and copper-containing protein in the metallothionein fraction was further subjected to DEAE Sephadex A-25 chromatography.

In the Sephadex G-75 chromatogram, most parts (about 90\%) of the urinary cadmium and copper were distributed in the metallothionein fraction, but no zinc was detected in this fraction. About $90 \%$ of the urinary zinc was recovered from nonprotein fractions near the bed volume. The other minor parts of these urinary metals were distributed broadly in protein fractions corresponding to higher molecular weights. In the control animals without cadmium injection, large parts of the urinary zinc and copper were recovered from the non-protein fractions near the bed volume and very small amounts of these metals were distributed in the high molecular-weight protein fractions. A trace amount of copper, but no zinc was detected in the metallothionein fraction.

The DEAE Sephadex A-25 chromatogram showed that cadmium and copper in the metallothionein fraction could be separated into four distinct peaks accompanied by corresponding peaks in the UV-absorbance at $250 \mathrm{~nm}$. The first two minor peaks were separated at the initial buffer concentration of $0.05 \mathrm{M}$ Tris$\mathrm{HCl}$; the other two main peaks were separated at buffer concentrations of 0.19 and $0.26 \mathrm{M}$, respectively. The separation profile of the latter two peaks was similar to that of hepatic metallothionein. These results indicated that most of the urinary cadmium and copper in the cadmium-poisoned rats was associated with metallothionein.
\end{abstract}

The low molecular-weight cadmium-binding protein, metallothionein ${ }^{1)}$ is synthesized mainly in the liver and kidney and probably in other tissues in response of cadmium exposure. This protein has also been shown to circulate in the blood in cadmiumexposed animals ${ }^{2-7)}$. Cadmium induced-metallothionein contains essential metals such as zinc and copper as well as cadmium in these organs $^{8-12)}$ and in erythrocytes ${ }^{7)}$. 


\section{Y. SUZUKI}

However, in the plasma, metallothionein contains only cadmium and copper, and no zinc ${ }^{\text {7). }}$.

Metallothionein has been suggested to have a variety of biological functions such as storage of these metals, protection from cadmium toxicity and metabolism of the metals as reviewed by Cherian and Goyer ${ }^{13)}$. Concerning the urinary excretion of cadmium, previous papers ${ }^{6,14,15)}$ have indicated that most of the urinary cadmium was associated with a protein having the same molecular weight as metallothionein in animals with signs of cadmium-induced renal damage. However, no studies has yet dealt with further separation of this metallothionein-like protein, and little attention has yet been paid to the copper- and zinc-binding properties of the protein in urine and its significance in the urinary excretion of these essential metals.

Since metallothionein has been separated into two to four metal-binding forms by anion exchange chromatography ${ }^{12,16-18)}$, this method was used in the present study for the further separation of the metallothionein-like protein prepared by Sephadex gel filtration of urine of cadmium-poisoned rats. Analysis of the separated fractions was performed for copper and zinc as well as cadmium.

\section{METHODS}

Animals and Treatment

Ten Sprague-Da wley male rats (7 weeks old) were individually housed in stainless steel metabolic cages and they were fed a commercial pelleted diet (CE-2, Japan CLEA Co., Ltd.) and sterilized tap water ad libitum. The cadmium, zinc and copper contents of the diet and of the tap water have been described in the previous paper ${ }^{7}$.

Five animals received a subcutaneous cadmium injection at a dose of $0.5 \mathrm{mg} \mathrm{Cd} / \mathrm{kg}$ body weight, 6 days per week. The injection schedule was the same as that used in previously reported experiments ${ }^{19)}$. The animals were weighed just before the injection every day and the total urinary excretion of protein was determined every week. These parameters were useful for monitoring of the cadmium toxicity. The remaining animals without cadmium injection were used as the control group.

After 14 weeks of exposure, the urine of the experimental animals was collected into ice-cooled vessels over a short period (3-4 hr) to avoid the risk of denaturation. The urine was immediately centrifuged at 3,000 r.p.m. for $10 \mathrm{~min}$ at room temperature and the supernatant was pooled. Urine from the control animals was collected and prepared in the same manner. These urinary preparations were then subjected to Sephadex G-75 chromatography.

\section{Sephadex G-75 Chromatography}

The urine preparations $(10 \mathrm{ml}$ each) from the experimental and control groups were separated by column chromatography $(2.6 \times 72 \mathrm{~cm})$ using Sephadex G-75 equilibrated with $0.05 \mathrm{M} \mathrm{NaCl}$, and $0.01 \mathrm{M}$ Tris $-\mathrm{HCl}$ buffer, $\mathrm{pH} 8.6$, containing $0.02 \%$ sodium azide. Calibration of the Sephadex column was performed with ribonuclease A, chymotrypsinogen $A$ and bovine serum albumin (Pharmacia, molecular weights: 13,700, 25,000 


\section{URINARY METALLOTHIONEIN IN Cd, Cu AND Zn EXCRETION}

and 67,000 , respectively). Elution of the urine samples was carried out with the same buffer solution at a speed of $20 \mathrm{ml} / \mathrm{hr}$ at room temperature and $4-\mathrm{ml}$ fractions were collected. These fractions were then subjected to UV-absorption measurement at 280 and $250 \mathrm{~nm}$, and to metal analysis for cadmium, zinc and copper by atomic absorption spectrophotometry. The analytical methods used here were the same as those described previously ${ }^{7)}$.

\section{DEAE Sephadex A-25 Chromatography}

The pooled solution containing a cadmium-binding protein recovered from the metallothionein fraction of the urine was subjected to DEAE Sephadex A-25 chromatography after concentration by ultrafiltration with UM-2 (Amicon). The methods of ultrafiltration, anion exchange chromatography and subsequent metal analysis were the same as described previously? ${ }^{\text {) }}$.

\section{RESUlts}

\section{Exposure Effects on Animal Health}

There was no significant difference in body weight gain between the experimental and control groups until 5 weeks of exposure. Thereafter, the weight of the experimental group was clearly less than that of the control one. Furthermore, the experimental group showed a decrease in body weight from around 10 weeks. Excretion of total protein in the urine of the exposed animals increased from 6 weeks and reached 3-4 times the control levels thereafter. These changing patterns of body weight and protein excretion were almost identical to those observed in previouly reported experiments ${ }^{19)}$.

Cadmium, Zinc and Copper Concentrations in Urine

Cadmium, zinc and copper concentrations of the pooled urine in the exposed animals were $3.11,1.22$ and $0.431 \mu \mathrm{g} / \mathrm{ml}$, respectively. In the control group, the urinary concentrations of zinc and copper were 0.307 and $0.270 \mu \mathrm{g} / \mathrm{ml}$, respectively, and a trace of cadmium was detected. These results indicated that cadmium exposure increased zinc and copper excretion in the urine.

\section{Sephadex G-75 Chromatograms}

Sephadex G-75 separation profiles of the urine preparations from the exposed and control groups are shown in Figs. 1 and 2, respectively. As seen in Fig. 1A, two UV-absorption peaks are apparent at protein fractions (30-50) of high molecular weight. A higher UV-absorption peak at $250 \mathrm{~nm}$ is seen at fractions 55 to 70 , which correspond to the elution fractions of metallothionein (metallothionein fraction). The extremely high peak of UVabsorbance at fractions 70 to 120 is due to non-protein substances in the urine. The other UV-absorption peaks clearly seen at the middle fraction numbers (50-60) in urine from the control group (Fig. 2) may be due to a sex-dependent rat urinary protein with a molecular-weight of $26,400^{20)}$.

Urinary cadmium was distributed in all the protein fractions. More than $90 \%$ of the total cadmium, however, was separated as a single peak with corresponding absorption 


\section{Y. SUZUKI}

peaks at 250 and $280 \mathrm{~nm}$ in the metallothionein fraction. This pattern of cadmium distribution is substantially consistent with previously reported results for mise ${ }^{14}$ and rats $^{6,15)}$ after long-term cadmium injection.

About $90 \%$ of the total copper in the urine of the exposed animals was separated as a clear-cut peak in the metallothionein fraction (Fig. 1B). The remaining parts of the urinary copper were broadly distributed in both the high-molecular-weight protein fractions (30-50) and non-protein fractions (80-90) near the bed volume of the Sephadex column. This distribution pattern of urinary copper in the exposed group was remarkably different from that in the control one. In the control group (Fig. 2), the

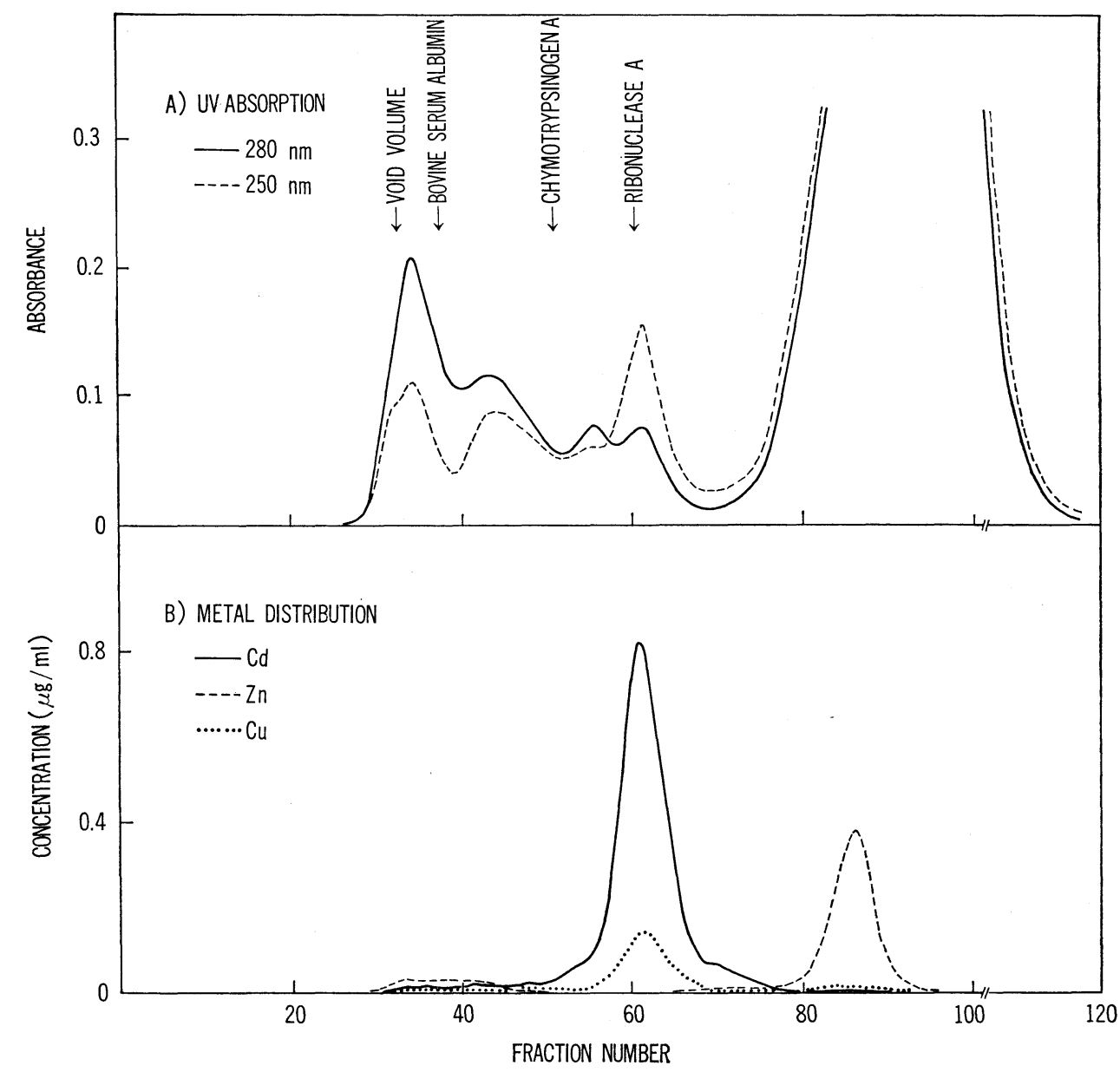

Fig. 1. Sephadex G-75 separation profile of urine from cadmium-exposed rats. Five male animals were given daily subcutaneous injections of cadmium chloride at a dose of $0.5 \mathrm{mg} \mathrm{Cd} / \mathrm{kg}$ body weight, 6 days per week. Urine was collected from the animals after 14 weeks of exposure and pooled. The pooled urine was filtrated on a Sephadex G-75 column $(2.6 \times 72 \mathrm{~cm})$ with $0.05 \mathrm{M} \mathrm{NaCl}$, and $0.01 \mathrm{M}$ Tris- $\mathrm{HCl}$ buffer, $\mathrm{pH} 8.6$, containing $0.02 \%$ sodium azide at a speed of $20 \mathrm{ml} / \mathrm{hr}$ and $4-\mathrm{ml}$ fractions were collected. 


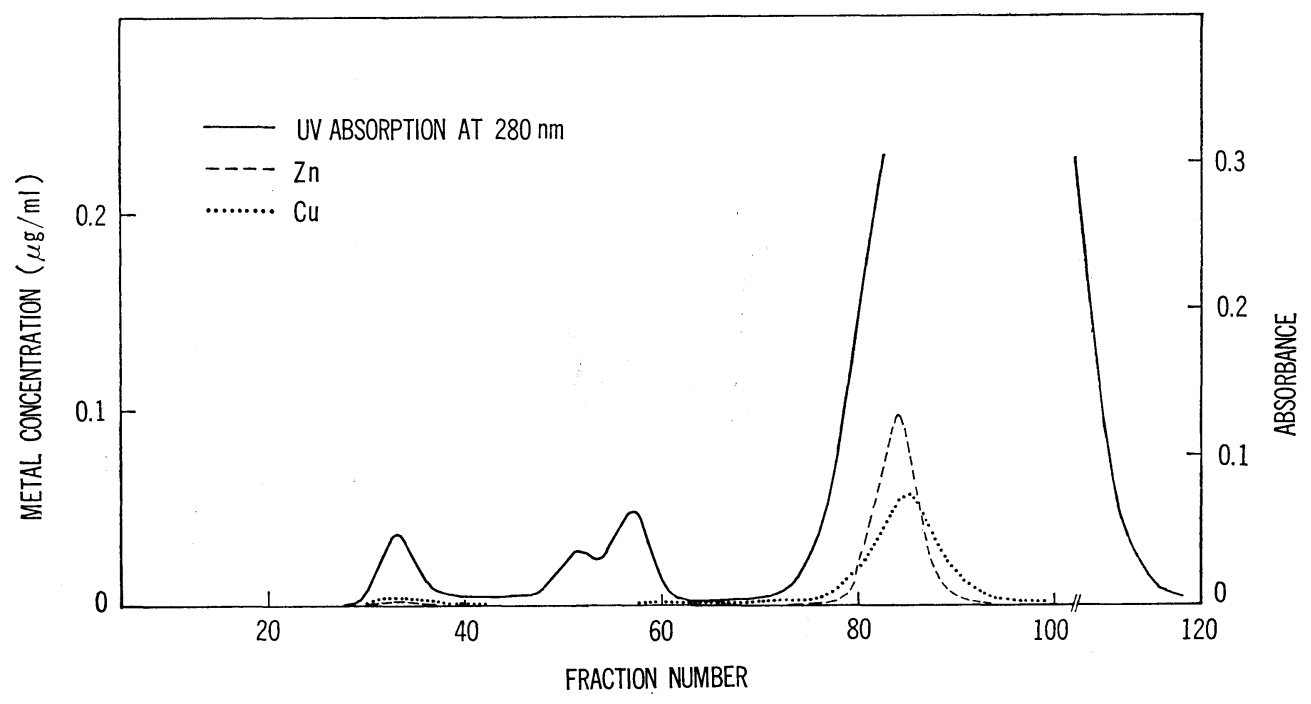

Fig. 2. Sephadex G-75 separation profile of urine from normal rats Urine was collected from 5 male animals without cadmium injection at the 14 th week of the experiment and pooled. The pooled urine was filtrated on a Sephadex G-75 column $(2.6 \times 72 \mathrm{~cm})$ with $0.05 \mathrm{M} \mathrm{NaCl}$, and $0.01 \mathrm{M}$ Tris- $\mathrm{HCl}$ buffer, $\mathrm{pH} 8.6$ containing $0.02 \%$ sodium azide at a speed of $20 \mathrm{ml} / \mathrm{hr}$ and $4-\mathrm{ml}$ fractions were collected.

non-protein fractions near the bed volume contained most $(88 \%)$ of the urinary copper as a single peak. The other parts of the urinary copper is distributed in the highmolecular-weight protein fractions; the metallothionein fraction contained only a trace amount of copper.

The urinary zinc was fractionated into two peaks in both the exposed and control groups (Figs. 1B and 2). One was a broad peak in the high-molecular-weight protein fractions and the other appeared as a high peak in the non-protein fractions near the bed volume. This peak held 89 and $98 \%$ of the total urinary zinc in the exposed and control groups, respectively. However, zinc was not detected in the metallothionein fraction in either group.

\section{DEAE Sephadex A-25 Chromatograms}

Further separation of the cadmium- and copper-containing low molecular-weight protein from the urine of the exposed animals was performed by DEAE Sephadex A-25 chromatography. The separation profile is shown in Fig. 3.

Cadmium was separated into at least four distinct peaks ( $\mathrm{P}-1$ to $\mathrm{P}-4)$. Each cadmium peak was accompanied by a UV-absorption peak at $250 \mathrm{~nm}$. The first two peaks were separated at the initial concentration $(0.05 \mathrm{M})$ of Tris- $\mathrm{HCl}$ buffer, while P-3 and P-4 were separated at buffer concentrations of 0.19 and $0.26 \mathrm{M}$ Tris- $\mathrm{HCl}$, respectively. All the cadmium peaks were accompanied by corresponding copper peaks. The greater parts of the urinary cadmium and copper were recovered from P-3 and 


\section{Y. SUZUKI}

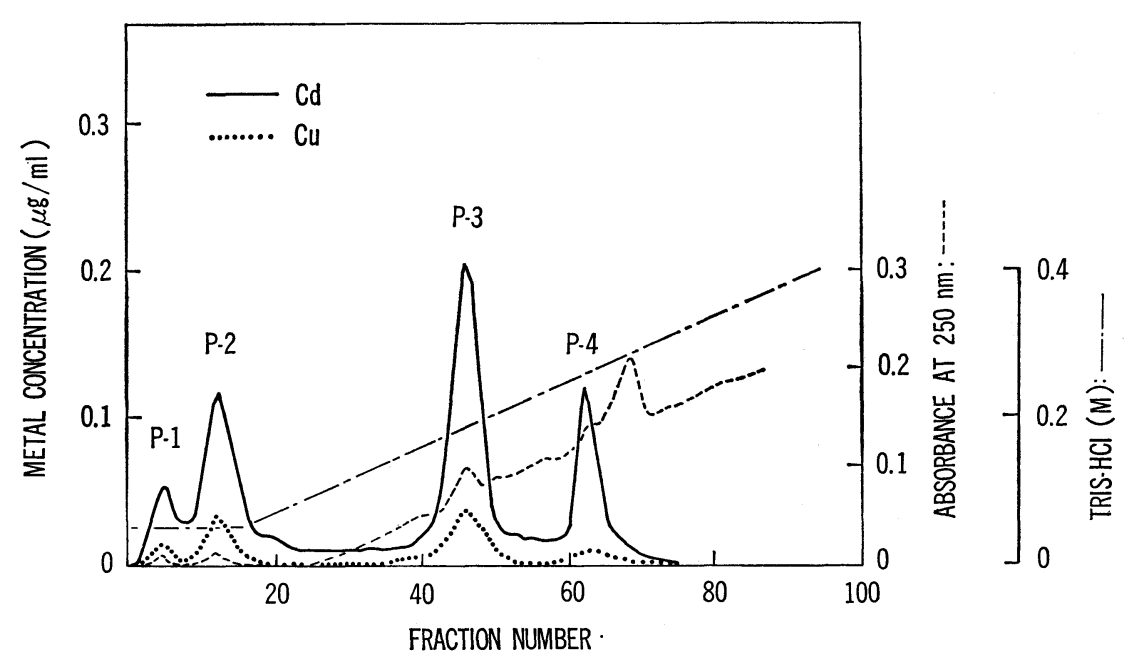

Fig. 3. DEAE Sephadex A-25 separation profile of a low molecular-weight cadmium and cooper-containing protein separated by Sephadex G-75 filtration of urine from cadmium-exposed rats. The urine was collected from 5 male animals after daily subcutaneous injections of cadmium chloride at a does of $0.5 \mathrm{mg}$ $\mathrm{Cd} / \mathrm{kg}$ body weight, 6 days per week for 14 weeks.

$\mathrm{P}-4$, and the $\mathrm{Cd}: \mathrm{Cu}$ molar ratios in the four peaks ranged from 2 to 6.8 as shown in Table 1.

Table 1. Metal distribution in four peaks on a DEAE. Sephadex A-25 chromatogram of a low-molecular-weight cadmium- and copperbinding protein* in urine from cadmium-poisoned rats.

\begin{tabular}{cccc}
\hline Peaks & $\mathrm{Cd}(\%)$ & $\mathrm{Cu}(\%)$ & $\mathrm{Cd}: \mathrm{Cu}$ molar ratio \\
\hline P-1 & 9 & 13 & 2.6 \\
P-2 & 21 & 37 & 2.0 \\
P-3 & 36 & 39 & 3.4 \\
P-4 & 20 & 11 & 6.8 \\
Others & 14 & - & - \\
\hline
\end{tabular}

* The protein was prepared by Sephadex G-75 separation of urine from male rats given daily subcutaneous injections of cadmium chloride at a dose of $0.5 \mathrm{mg} \mathrm{Cd} / \mathrm{kg}$ for 14 weeks.

\section{Discussion}

The present study was undertaken to investigate the anion exchange chromatographic properties of a urinary low molecular-weight cadmium-binding protein and its role in the excretion of copper and zinc as well as cadmium in the urine of cadmium-poisoned rats. The experimental animals were given repeated subcutaneous 


\section{URINARY METALLOTHIONEIN IN Cd, Cu AND Zn EXCRETION}

injections of $0.5 \mathrm{mg} \mathrm{Cd} / \mathrm{kg}$ body weight and the examination was performed after 14 weeks of exposure. During this period, the body weight and total protein excretion in the urine were monitored. The results indicated that the disease state at the last week reached stage III on the previously reported classification of experimental cadmium poisoning ${ }^{19)}$. That paper states that stage III is characterized by liver injury in addition to renal damage that has progressed from the previous toxic stage (stage II).

The anion exchange chromatographic profile of the urinary metallothionein fraction (Fig. 3) confirms the early suggestion by Norberg et al. ${ }^{14}$ that the low molecular-weight cadmium-binding protein in the urine of animals with signs of cadmium-induced renal lesions is metallothionein. In the present experiment four cadmium peaks were found on DEAE Sephadex A-25 chromatograms of the low-molecular-weight cadmium-binding protein in the urine of cadmium-poisoned rats. The separation profile of the two major peaks (P-3 and P-4) was similar to that of the two well-known forms (MT-1 and MT-2) of hepatic and renal metallothionein ${ }^{12,16-18)}$.

Concerning the cadmium-containing components of the first two peaks $(\mathrm{P}-1$ and $\mathrm{P}-2$ ), their real nature and the significance of their existence are still not clear. They could represent transitional forms of metallothionein, probably denatured in vivo. However, the possibility cannot be excluded that they might be artifacts produced in the preparation procedure as suggested by Kimura et al. ${ }^{17}$ in their studies on renal metallothionein.

A large amount of cadmium was shown to be excreted in the form of metallothionein at this experimental time. The increased excretion of cadmium metallothionein probably reflects a raised metallothionein level in the plasma. It has been shown that considerable amounts of cadmium metallothionein, when this substance was injected intravenously at high doses, were excreted into the urine almost intact ${ }^{21,22}$. A previous study ${ }^{23)}$ suggests that cadmium-induced hepatic injury causes an increase in the cadmium metallothionein level in the plasma probably as a result of an abnormally high rate of metallothionein discharge from the liver into the blood. It is suggested, therefore, that the excess excretion of cadmium metallothionein in the urine as observed here may be a consequence of the hepatic injury; probably, the renal damage is also involved in the high excretion of the metal protein in urine.

The present results indicate that cadmium exposure increases the excretion of copper and zinc in urine. This is in agreement with the results of Bonner et $\mathrm{al}^{24)}$. Furthermore, the present results reveal that urinary copper as well as cadmium, but not zinc, are associated with metallothionein (Fig. 1). Such metal-binding characteristics of urinary metallothionein are identical to those of the plasma metallothionein in cadmiumexposed rats $^{7)}$, but clearly different from those of the cadmium-induced metallothionein in visceral organs, which contains mainly cadmium and zinc ${ }^{1}$. This apparent discrepancy in metal-binding characteristics between hepatic and plasma or urinary metallothionein may important to the elucidation of the metallothionein role in the urinary excretion of copper and zinc. It has been shown that the binding affinity of metal- 


\section{Y. SUZUKI}

lothionein to copper and cadmium irons is higher than that of zinc ions ${ }^{25-27)}$. Therefore, zinc of metallothionein that was released from the liver into the blood as a result of the hepatic injury might be replaced by plasma copper. As a result copper-rich cadmium metallothionein should be formed in the plasma ${ }^{23)}$. Such replacement has been demonstrated in an in vitro experiment ${ }^{28}$. An increase in the copper-rich cadmium metallothionein in the plasma may be responsible for the excess excretion of copper associated with metallothionein in the urine.

Zinc released from the metallothionein into the plasma by the above mechanism may form zinc complexes with higher molecular-weight plasma proteins, probably albumin and globulins, and also with lower molecular-weight components, probably such as amino acids in the plasma. The latter zinc complexes appear to contribute to some extent to the excretion of zinc as low-molecular-weight non-protein complexes in the urine. This fate of zinc of metallothionein in the plasma may be supported by the observation of Cherian ${ }^{29)}$ that in rats injected intravenously with ${ }^{65} \mathrm{Zn}$-thionein, a considerable portion of the isotope was excreted into the urine as a low-morecular-weight complex, but not in the metallothionein form. It is sugested, therefore, that the above mechanism of the excess excretion of metallothionein in urine possibly results in disturbance of the metabolism of copper and zinc.

\section{ACKNOWLEDGEMENT}

The author wishes to thank Dr. M. Kimura in our institute for helpful discussion and suggestions during this work.

\section{REFERENCES}

1) Kojima, Y. and Kägi, J.H. R. (1978). Trends Biochem. Sci., 3, 90.

2) Nordberg, G. F., Piscator, M. and Nordberg, M. (1971). Pharmacol. et Toxicol., 30, 289.

3) Cherian, M. G., Goyer, R. A. and Delaquerriere-Richardson, L. (1977). Toxicol. Appl. Pharmacol., 41, 145.

4) Vander Mallie, R. J. and Garvey, J. S. (1979). J. Biol. Chem., 254, 8416.

5) Nordberg, M. (1978), Environ. Res., 15, 381.

6) Shaikh, Z. A. and Hirayama, K. (1979). Environ, Health Perspect., 28, 267.

7) Suzuki, Y. (1980). Ind. Health, 18, 19.

8) Webb, M. (1972), Biochem. Pharmacol., 21, 2751.

9) Snzuki, Y. and Yoshikawa, H. (1974), Ind. Health, 12, 141.

10) Kimura, M. and Otaki, N. (1975). Ind. Health, 13, 203.

11) Sugawara, N. (1977). Toxicol. Appl. Pharmacol., 42, 377.

12) Suzuki, K. T. and Yamamura, M. (1979). Arch. Environ. Contam. Toxicol., 8, 471.

13) Cherian, M. G. and Goyer, R. A. (1978). Life Science, 23, 1.

14) Nordberg, G. F. and Piscator, M. (1972). Environ. Physiol. Biochem. 2, 37.

15) Suzuki, Y. (1977). Jap. J. Ind. Health, 19, 200. (In Japanese) 


\section{URINARY METALLOTHIONEIN IN Cd, Cu AND Zn EXCRETION}

16) Shaikh, Z. A. and Lucis, O. J. (1971). Experientia, 27, 1024.

17) Kimura, M., Otaki, N., Yoshiki, S., Suzuki, M., Horiuchi, N. and Suda, T. (1974). Arch Biochem. Biophys., 165, 340.

18) Feldman, S. L., Squibb, K.S. and Cousins, R. J. (1978) J. Toxicol. Environ. Health, 4, 805.

19) Suzuki, Y. (1980). J. Toxicol. Environ. Health, 6, 469.

20) Roy, A. K., Neuhaus, O. W. and Harmison, C. R. (1966), Biochim. Biophys. Acta, $127,72$.

21) Cherian, M. G. and Shaikh, Z. A. (1975). Biochem. Biophys. Res. Comm., 65, 863.

22) Tanaka, K., Sueda, K., Onosaka, S. and Okahara, K. (1975). Toxicol. Appl. Pharmacol., $33,258$.

23) Suzuki, Y. J. Toxicol. Environ. Health (in press.).

24) Bonner, F. W., King, L. J. and Parke, D. V. (1979). Chem. Biol. Interactions, 27, 343.

25) Rupp, H. and Weser, U. (1974). FEBS Letters, 44, 293.

26) Suzuki, K. T., Kubota, K. and Takenaka, S. (1977). Chem. Pharm. Bull. 25, 2792.

27) Onosaka, S., Tanaka, K., Sueda, K. and Okahara, K. (1976). J. Hygienic Chem., $22,206$.

28) Suzuki, Y. (1979). Jap. J. Ind. Health, 21, 617. (Proceedings of the 52nd Annual Meeting of Japan Association of Industrial Health, in Japanese)

29) Cherian, M. G. (1977). J. Nutr., 107, 965. 